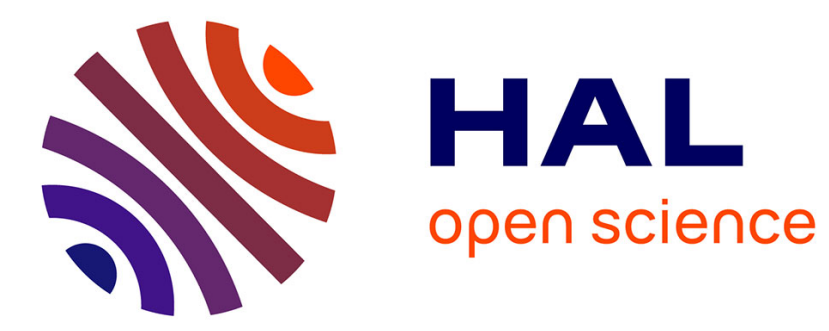

\title{
CDC50A plays a key role in the uptake of the anticancer drug perifosine in human carcinoma cells
}

Francisco Muñoz-Martínez, Cristina Torres, Santiago Castanys, Francisco Gamarro

\section{- To cite this version:}

Francisco Muñoz-Martínez, Cristina Torres, Santiago Castanys, Francisco Gamarro. CDC50A plays a key role in the uptake of the anticancer drug perifosine in human carcinoma cells. Biochemical Pharmacology, 2010, 80 (6), pp.793. 10.1016/j.bcp.2010.05.017 . hal-00608936

\section{HAL Id: hal-00608936 https://hal.science/hal-00608936}

Submitted on 16 Jul 2011

HAL is a multi-disciplinary open access archive for the deposit and dissemination of scientific research documents, whether they are published or not. The documents may come from teaching and research institutions in France or abroad, or from public or private research centers.
L'archive ouverte pluridisciplinaire HAL, est destinée au dépôt et à la diffusion de documents scientifiques de niveau recherche, publiés ou non, émanant des établissements d'enseignement et de recherche français ou étrangers, des laboratoires publics ou privés. 


\section{Accepted Manuscript}

Title: CDC50A plays a key role in the uptake of the anticancer drug perifosine in human carcinoma cells

Authors: Francisco Muñoz-Martínez, Cristina Torres, Santiago Castanys, Francisco Gamarro

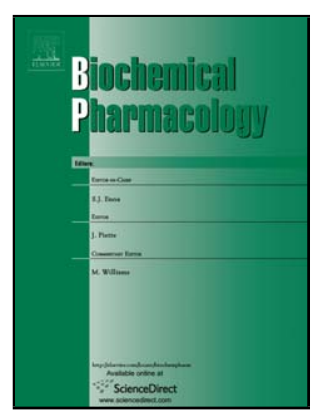

PII:

S0006-2952(10)00356-4

DOI: doi:10.1016/j.bcp.2010.05.017

Reference: BCP 10572

To appear in: $\quad B C P$

Received date: $\quad 10-2-2010$

Revised date: $\quad 13-5-2010$

Accepted date: $\quad$ 17-5-2010

Please cite this article as: Muñoz-Martínez F, Torres C, Castanys S, Gamarro F, CDC50A plays a key role in the uptake of the anticancer drug perifosine in human carcinoma cells, Biochemical Pharmacology (2008), doi:10.1016/j.bcp.2010.05.017

This is a PDF file of an unedited manuscript that has been accepted for publication. As a service to our customers we are providing this early version of the manuscript. The manuscript will undergo copyediting, typesetting, and review of the resulting proof before it is published in its final form. Please note that during the production process errors may be discovered which could affect the content, and all legal disclaimers that apply to the journal pertain. 


\section{TITLE:}

CDC50A plays a key role in the uptake of the anticancer drug perifosine in human carcinoma cells

\section{AUTHOR NAMES AND AFFILIATION:}

Francisco Muñoz-Martínez ${ }^{\text {a, }}{ }^{\text {, }}$ Cristina Torres ${ }^{a}$, Santiago Castanys ${ }^{\text {a, }, ~ a n d ~}$ Francisco Gamarro a, \#

anstituto de Parasitología y Biomedicina "López-Neyra", Consejo Superior de Investigaciones Científicas. Parque Tecnológico de Ciencias de la Salud, Avenida del Conocimiento s/n, 18100 Armilla, Granada. Spain.

"Corresponding author. Mailing address of Francisco Gamarro: Instituto de Parasitología y Biomedicina López-Neyra, CSIC, Parque Tecnológico de Ciencias de la Salud, Avda. del Conocimiento s/n, 18100 Armilla, Granada, Spain. Phone: 34 958 181667. Fax: 34958 181632. E-mail: gamarro@ipb.csic.es. For Santiago Castanys, phone: +34 958 181666; fax: +34 958 181632, e-mail:

castanys@ipb.csic.es

${ }^{1}$ Present address: Estación Experimental del Zaidín (CSIC), Profesor Albareda, 1. Granada. 18008. SPAIN 


\section{ABSTRACT:}

Functional aminophospholipid translocases are composed of at least two proteins: an alpha subunit from the P4 subfamily of P-type ATPases and a beta subunit from the CDC50-Lem3p family. Over-expression and knockdown of the human beta subunit CDC50A in KB cells enhanced and decreased, respectively, the uptake of both fluorescent aminophospholipid analogues and the anticancer alkylphospholipid perifosine. Confocal microscopy showed that CDC50A-V5 was localized at the endoplasmic reticulum and the Golgi complex of both KB (perifosinesensitive) and KB PER-R (perifosine-resistant, alkyl-phospholipid uptake deficient) cells, but was only widely distributed in the early and late endosomes in KB cells. Biotinylation of cell surface proteins allowed CDC50A-V 5 to be detected in the plasma membrane of KB cells but not in KB PER-R cells, thereby suggesting a defect in CDC50A trafficking that could explain the inability of KB PER-R to uptake perifosine. Over-expression of CDC50A in HeLa and HEK293T cells did not increase uptake, since the protein was retained at the endoplasmic reticulum and Golgi. However, when CDC50A was co-expressed with the P4-ATPase Atp8b1, the two proteins co-localized at the plasma membrane and the uptake of aminophospholipids and perifosine increased strikingly in both cell lines. These findings suggest that CDC50A plays a key role in perifosine uptake in human cells, presumably by forming a functional plasma membrane translocator in combination with a P4-ATPase.

KEYWORDS: perifosine uptake, CDC50A, Atp8b1, P4-ATPase, aminophopholipid translocase, resistance to perifosine, cancer chemotherapy. 


\section{INTRODUCTION}

Perifosine is an oral alkyl-phospholipid (ALP) Akt inhibitor that is currently being tested in phase II clinical trials. Unlike most kinase inhibitors, which target the adenosine triphosphate-binding region, perifosine targets the pleckstrin homology domain of Akt, thereby preventing its translocation to the plasma membrane [1]. Single-agent activity with perifosine has been observed in sarcoma and Waldenström macroglobulinemia patients [2]. However, the disappointing response rates of common solid tumors to perifosine as a single agent [3-6] have diminished expectations and prompted further investigation into its mechanism of action.

The ability to identify patients likely to respond to targeted therapeutics would decrease the size, duration, and cost of clinical trials, thus resulting in more efficient translation to improved patient outcomes. In this sense, Hennessy and co-workers [7] reported a strong correlation between proportional modulation of PI3K pathway biomarkers and quantified perifosine efficacy, thereby suggesting that the early measurements of such biomarkers will optimize the selection of responsive patients and guide perifosine dosage during cancer treatment. Furthermore, the identification of other potential biomarkers for perifosine efficacy in cancer patients would allow those patients most likely to respond to perifosine, either alone or in combination with other therapies, to be selected.

ALP uptake is a prerequisite for triggering the intracellular events that finally cause cell death in different cellular systems, including yeasts [8,9], the protozoan parasite Leishmania donovani [10] and cancer cells [11]. Indeed, a clear correlation between ALP uptake and apoptosis induction has been reported previously [12]. Two pathways for the entry of ALP into cancer cells, namely raft-mediated endocytosis in lymphoma cells [13] and translocator-mediated uptake in carcinoma 
cells [14-16], have been described. A clearer insight into the molecular determinants of perifosine entry into cancer cells would therefore be of enormous importance for the identification of additional biomarkers for the efficacy of perifosine as an anticancer drug.

Data from our previous work [14] strongly supported the hypothesis that a putative aminophospholipid translocase (APLT; P-type ATPase P4 subfamily) could be responsible for the uptake of ALPs in human KB carcinoma cells. Indeed, the plasma membrane P4-ATPase homologues of yeast and Leishmania have been shown to play a key role in the uptake of miltefosine and edelfosine $[9,17]$ in combination with a second protein from the Cdc50p-Lem3p family that functions as a beta subunit $[8,10,18,19]$. As fourteen putative APLTs [20] and only three beta subunits (CDC50A, B and C) [21] have been identified in humans, we decided to try to elucidate the role of these human beta subunits as functional elements of the putative plasma membrane perifosine translocator (and other related ALPS) in cancer cells, and found that CDC50A plays a key role in the uptake of perifosine in human cancer cells, presumably by forming a functional plasma membrane translocator in combination with a P4-ATPase.

\section{MATERIALS AND METHODS}

2.1. Chemicals. Perifosine (octadecyl-[N,N-dimethyl-piperidinio-4-yl]-phosphate), and $\left[{ }^{14} \mathrm{C}\right]$-perifosine $(30.9 \mathrm{mCi} / \mathrm{mmol})$ were provided by Zentaris $\mathrm{GmbH}$ (Frankfurt, Germany). Lipofectamine 2000, Anti-V5 monoclonal antibody, Alexa Fluor 633conjugated anti-mouse IgG, pEF6-V5/His and pcDNA3.1-HYGRO vectors, FITCconcanavalin A, BODIPY-lactosylceramide, and Alexa Fluor 488-labeled dextran 
10,000 were purchased from Invitrogen (Prat de Llobregat, Barcelona, Spain). Predesigned ON-TARGETplus siRNA for human CDC50A and CDC50B were purchased from Dharmacon (Lafayette, CO). Fluorescent (NBD-labeled) phospholipid analogues 1-palmitoyl-2-\{6-[(7-nitro-2-(1,3-benzoxadiazol)-4yl)amino]hexanoyl\}-sn-glycero-3-phosphoethanolamine (NBD-PE), -phosphoserine (NBD-PS) and -phosphocholine (NBD-PC) were purchased from Avanti Polar Lipids (Alabaster, AL). Anti-rabbit IgG monoclonal antibody, monoclonal anti-a-tubulin antibody, and the rabbit polyclonal antibodies anti-myc, anti-calnexin, anti-GM130, anti-TGN46, anti-Rab5 and anti-Rab7, and MTT [3-(4,5-Dimethylthiazol-2-yl)-2,5diphenyltetrazolium bromide] were purchased from Sigma-Aldrich (Madrid, Spain). Fugene HD, High Pure RNA isolation kit and Expand High Fidelity PCR System were purchased from Roche (San Cugat del Vallés, Barcelona, Spain), and the High-capacity cDNA Reverse transcription kit plus RNAse inhibitor from Applied Biosystems (Alcobendas, Madrid, Spain). The Perfectprep ${ }^{\circledR}$ plasmid isolation kit from Eppendorf lbérica (San Sebastian de los Reyes, Madrid, Spain) was used to isolate purified plasmids. QuickChange II XL Site-directed Mutagenesis kit was purchased from Stratagene-Cultek SLU (Madrid, Spain), and the pGEM-T Easy vector from Promega Biotech Ibérica (Alcobendas, Madrid, Spain). All other chemicals were purchased from Sigma-Aldrich (Madrid, Spain).

2.2. Cell lines and cultures. The mammalian cell lines described in the present work were grown at $37{ }^{\circ} \mathrm{C}$ in a humidified atmosphere and $5 \% \mathrm{CO}_{2}$ in Dulbecco's Modified Eagle Medium (DMEM) supplemented with 10\% (v/v) fetal bovine serum (FBS), 2 mM Glutamax I, 1:50 Micokill AB solution 50X (PAA Laboratories GmbH) and $250 \mathrm{U} / \mathrm{ml}$ penicillin G plus $250 \mu \mathrm{g} / \mathrm{ml}$ streptomycin sulphate (Invitrogen), unless indicated otherwise. The following cells were used: murine fibroblast embryo NIH 
3T3 cells (ATCC number CCL-1658); chinese hamster ovary CHO-K1 cells (ATCC number CCL-61; cultured in F-12K medium); canine kidney MDCKII cells [22]; monkey epithelial kidney Vero and COS-7 cells (ATCC CRL-1586 and CRL-1651); human epidermal carcinoma KB cells (wild-type) (ATCC number CCL-17) and its perifosine-resistant counterparts KB PER-R clone 4, 8 and 10 [14]; human breast carcinoma MCF-7 and MDA-MB-23 cells [23, 24]; human cervix epithelial adenocarcinoma HeLa cells (ATCC CCL-2); human epithelial embryonic kidney HEK-293T cells (ATCC CRL-11268); human pancreas carcinoma AsPC1 and MiaPaca2 cells (ATCC CRL-1682 and CRL-1420); human 2008 ovary cells [25], kindly provided by Prof. Piet Borst (Division of Molecular Biology, The Netherlands Cancer Institute, Amsterdam, The Netherlands); and human osteosarcoma HOS cells (ATCC CRL-1543).

\footnotetext{
2.3. MTT survival assays, $\left[{ }^{14} \mathrm{C}\right]$-perifosine uptake, accumulation of fluorescent phospholipid analogues and measurement of endocytosis rates. Unless otherwise indicated, these four different assays were performed as described in our previous work [14], with the only modification that, in the MTT-based colorimetric assay to determine perifosine sensitivity, the cell lines were incubated with the anticancer drug for only $2 \mathrm{~h}$ instead of $24 \mathrm{~h}$ before adding MTT to the culture medium. This modification allowed us to better link the observed cytotoxicity with the amount of perifosine incorporated in a short time by each cell line, and therefore to establish whether cell death actually correlated with intracellular accumulation of perifosine.
}

\subsection{Isolation of $C D C 50 A, C D C 50 B$ and Atp8b1, and DNA constructs. The} human cDNAs of CDC50A (GenBank accession no. NM 018247, longer transcription variant 1) and $C D C 50 B$ (GenBank accession no. NM 001017970) 
genes, which code for the putative beta subunits of the human APLT(s) (P-type ATPase P4 subfamily), were isolated by RT-PCR with the High Capacity cDNA Reverse transcription kit plus RNAse inhibitor (Applied Biosystems), using total RNA obtained from KB cells with the High Pure RNA isolation kit (Roche) as template; [primers: CDC50A-F (5'-ACCATGGCGATGAACTATAACG), and CDC50A-R (5'TTAAATGGTAATGTCAGCTGTATTAC); CDC50B-F (5'ACCATGACCTGGAGCGCCACGGC) and CDC50B-R (5'TCACTCCTCGTCGTCGTCCTGG)]. The resulting PCR products were cloned into the pEF6-V5/His TOPO TA expression vector from Invitrogen, in frame with the Cterminal V5 epitope and the polyhistidine ( 6 x His) tag. The cDNA of Atp8b1 (GenBank accession no. $\underline{\text { BC117946) }}$, the murine orthologue of the human gene that encodes for the putative APLT ATP8B1 (95\% identity), was purchased from Source BioScience Geneservice (Cambridge, UK) as a full open-reading frame (ORF) cloned into pCR-BluntII-TOPO vector. The construct was isolated and purified using the Perfectprep ${ }^{\circledR}$ plasmid isolation kit (Eppendorf), and the ORF subsequently amplified using the Expand High Fidelity PCR System with the primers: 8b1-F (5'ACCATGGGCACAGAAAGAGACTCG); 8b1-R (5'TCACAGATCCTCTTCAGAGATGAGTTTCTGCTCGCTCTCCACTGTGCGCCGGTA ), (myc-tag coding sequence underlined). The resulting PCR product was cloned into pGEMT-Easy from Promega. The nucleotide sequences of all cloned cDNAs were determined automatically, as described previously [26], and compared against their respective records annotated in GenBank. Unexpectedly, after repeating PCR and isolating new clones, we found that the supplier had provided us with a mutant variant of the Atp8b1 gene (A1954G, which resulted in the amino acid mutation $\mathrm{R} 652 \mathrm{G})$. Since we were concerned about the possible undesired effects that this 
mutation could cause in the phenotypic function of the resulting protein, we decided to fix it by using the QuickChange II XL Site-directed Mutagenesis kit from Stratagene using the primers (fixing point-mutation is underlined): FAtp8b1-mut (5'AAGTGAGACTCTCAGGACCCTGTGCCTGTG); RAtp8b1-mut (5'CACAGGCACAGGGTCCTGAGAGTCTCACTTG). Once this annoying problem had been resolved, we re-amplified the Atp8b1 ORF with the primers FAtp8b1-Nhel (5'TTATTGCTAGCACCATGGGCACAGAAAGAGACTCG); RAtp8b1-BamHI (5'TTATTGGATCCTCAAGATCTCTTCAGAGATGAG), and cloned the resulting PCR product as an Nhel/BamHI fragment into the pcDNA3.1-HYGRO expression vector.

2.5. Cell transfection. KB Wt, KB PER-R, HeLa and HEK-293T cells were stably transfected with pEF6-CDC50A-V5 and pEF6-CDC50B-V5 using Lipofectamine 2000 following the manufacturer's protocol. The stable transfectants were selected with $10 \mu \mathrm{g} / \mathrm{ml}$ blasticidin in only one week, and the expression levels of both proteins readily visualized by Western blotting or indirect immunofluorescence (IFI) under a microscope using monoclonal anti-V5 1:5000 from Invitrogen. Untransfected and CDC50A-V5-transfected KB Wt and KB PER-R cells were refractory to both stable and transient transfection with the pcDNA3.1-HYGRO-Atp8b1-myc construct using either Lipofectamine 2000 or Fugene HD, as judged by the fact that no Atp8b1-myc expression was observed, either by Western blot or by IFI using several anti-myc antibodies. In contrast, HeLa and HEK-293T cells could be transiently transfected with CDC50A-V5 alone or in combination with Atp8b1-myc, with the best results being obtained using Fugene HD.

2.6. siRNA-based CDC50A and CDC50B knockdown. Human CDC50A and CDC50B were targeted using SMARTpool siRNA oligonucleotides (Dharmacon), 
following a previously described procedure [14], at concentrations of 1, 10 and 100 $\mathrm{nM}$ of siRNA oligonucleotides in order to monitor the concentration dependency of the gene silencing.

2.7. Biotinylation of cell surface proteins. KB Wt and PER-R cells were washed with PBS and incubated on ice with $1 \mathrm{mM}$ EZ-Link Sulfo-NHS-SS-biotin (Thermo Scientific Pierce, Madrid, Spain) in $1 \mathrm{ml}$ PBS for $2 \mathrm{~h}$ at $4{ }^{\circ} \mathrm{C}$. The biotinylation reaction was quenched by washing the cells three times with $50 \mathrm{mM}$ Tris- $\mathrm{HCl}, \mathrm{pH} 7.4$, then cells were incubated on ice for $30 \mathrm{~min}$ in $100 \mu \mathrm{l}$ lysis buffer (50 mM Tris- $\mathrm{HCl} \mathrm{pH} \mathrm{7.4,} 150 \mathrm{mM} \mathrm{NaCl}, 1 \%$ Nonidet P-40) plus a protease inhibitor cocktail (Sigma-Aldrich). The cell lysate was clarified by centrifugation at $21,000 \times g$ for 10 min at $4{ }^{\circ} \mathrm{C}$, and the supernatant incubated for $2 \mathrm{~h}$ at $4{ }^{\circ} \mathrm{C}$ in continuous agitation with $100 \mu$ l of packed streptavidin-agarose beads (Thermo Scientific Pierce) pre-washed with lysis buffer. The agarose beads were then washed three times with $1 \mathrm{ml}$ of PBS $+1 \mathrm{M} \mathrm{NaCl}$ and two times with $1 \mathrm{ml}$ of PBS, and the biotinylated proteins eluted in $30 \mu \mathrm{l}$ of $2 \times$ Laemmli buffer.

2.8. Immunoblotting. Protein samples were fractionated by SDS-PAGE under standard conditions and electrotransferred onto Immobilon P membranes (Millipore, Bedford, MA). Immunodetection of the V5-tagged beta subunits and Atp8b1-myc was performed with 1:5000 monoclonal anti-V5 and 1:1000 anti-myc polyclonal antibody in buffer A (PBS containing $0.01 \%$ Tween 20 and $0.1 \%$ BSA). After washing, the membranes were incubated with horseradish peroxidase-conjugated secondary rabbit anti-mouse or goat anti-rabbit (1:5000) immunoglobulin G (Dako, Barcelona, Spain) in buffer A. Immunodetection of $\alpha$-tubulin for sample normalization 
was performed with monoclonal anti- $\alpha$-tubulin antibody (Sigma-Aldrich) at 1:5000.

Signals were detected using either the ECL or the ECL Plus chemiluminescent substrate (Thermo Scientific Pierce).

\subsection{Immunofluorescence and confocal microscopy. Cells were seeded onto} cover slip circles (diameter: $12 \mathrm{~mm}$; thickness: 0.13-0.16 mm, from MenzzelGlässer) in 24-well plates (Thermo Scientific Nunc, Madrid, Spain) and cultured under standard conditions. On the day of the experiment, the cells were washed three times with PBS and fixed with 2\% para-formaldehyde in PBS for 20 min at room temperature. After quenching with $10 \mathrm{mM}$ Tris- $\mathrm{HCl} \mathrm{pH} 7.4$ and washing twice with the same buffer, the cells were permeabilized with a $0.1 \%$ solution of Triton X100 detergent (Sigma-Aldrich) in PBS for $10 \mathrm{~min}$ at room temperature. They were then washed with PBS and incubated for 30 min with PBS 1\% BSA to block the nonspecific binding of antibodies. The primary antibodies anti-V5 (1:5000), anti-myc (1:1000), anti-calnexin (1:200), anti-GM130 (1:2500), anti-TGN46 (1:200), anti-Rab5 (1:200) and anti-Rab7 (1:200) were incubated at $37^{\circ} \mathrm{C}$ in a humidified atmosphere for $1-2 \mathrm{~h}$ in PBS $1 \% \mathrm{BSA}$. The cells were then rinsed three times with PBS and treated with the secondary antibodies FITC-conjugated anti-rabbit $\lg G$ antibody (1:1000-1:2000) from Sigma-Aldrich, and AlexaFluor 633-conjugated anti-mouse IgG antibody (1:500) from Invitrogen in PBS 1\% BSA. After the labelling procedure was complete, the cells were washed three times with PBS and mounted onto glass slides using Prolong Gold mounting medium with DAPI (Invitrogen).

Confocal images were acquired using a Leica TCS-SP5 confocal scanning laser microscope equipped with $\mathrm{Ar}$ and He-Ne lasers and connected to a Leica DMIRBE inverted epi-fluorescence microscope. The following filter settings were used: DAPI 
(blue): excitation at $405 \mathrm{~nm}$ (405 diode laser, UV), emission at 409-469 nm; FITC (green): excitation at $458 \mathrm{~nm}$ (argon laser, 20\% power), emission at $494-603 \mathrm{~nm}$; Alexa Fluor 633 (red): excitation at 633nm (633 HeNe laser, 20\% power), emission at $648-692 \mathrm{~nm}$. Serial fluorescence images were obtained using the $63 \times$ objective and processed and assembled with LAS AF Leica confocal software. Image analysis and subcellular colocalization fluorograms were generated and analyzed using the Leica confocal software package.

2.10. Semi-quantitative RT-PCRs. Semi-quantitative RT-PCRs were performed using the total cDNAs synthesized above as templates to establish the endogenous expression of CDC50A and ATP8B1 genes in KB, HeLa and HEK293T cells.

Standard PCRs were performed using serial dilutions of total CDNAs as templates and highly specific primers [ATP8B1 forward (5'-CAG ACT GCA TAC GAG GAT TGG); ATP8B1 reverse (5'-CCT TCA ACC GCT TGC GAT G); CDC50A forward (5'CTA TAA CGC GAA GGA TGA AGT G); CDC50A reverse (5'- TCC ATA ATA CAT AAA CAC GTT GCC); $\beta$-actin forward (5'-CCT CAT GAA GAT CCT CAC CG); $\beta$ actin reverse (5'-CAG TGA TCT CCT TCT GCA TCC)] to amplify internal 631-, 357and 660-bp sequences from the ATP8B1, CDC50A and $\beta$-actin cDNAs, respectively. The PCR conditions for each step were as follows: Initial denaturation (95 ํㅡ, $5 \mathrm{~min})$; 35 cycles (denaturation: $92^{\circ} \mathrm{C}, 30 \mathrm{~s}$; annealing: $52^{\circ} \mathrm{C}, 45 \mathrm{~s}$; extension: $72{ }^{\circ} \mathrm{C}, 45 \mathrm{~s}$ ); final extension: $72 \stackrel{\circ}{\circ}$, 3 min. The resulting PCR products were run in $0.8 \%$ agarose gels stained with ethidium bromide and visualized in a UV transiluminator. 


\section{RESULTS}

\subsection{Perifosine and NBD-phosphatidylethanolamine (NBD-PE) uptake are linked processes in KB cell lines}

In our previous work we generated a perifosine-resistant line (designated as KB PER-R clone 10) from the perifosine-hypersensitive KB Wt cells (with an $\mathrm{EC}_{50}$ of less than $1 \mu \mathrm{M}$ for $24 \mathrm{~h}$ perifosine exposure). Along with a high resistance to perifosine (grows suitably at $20 \mu \mathrm{M}$ perifosine), this cell line showed significantly decreased perifosine uptake, a low rate of NBD-aminophospholipid translocation through the plasma membrane, a relatively high exposure of endogenous phosphatidylserine in the cell surface, and lacked NEM- and orthovanadatesensitive, plasma-membrane-associated ATPase activity [14]. Similar perifosineresistant clones generated in our laboratory from KB Wt cells (clones 4 and 8 ) showed intermediate levels of perifosine uptake with respect to KB cells and KB PER-R clone10 cells, along with intermediate rates of NBD-PE translocation through the plasma membrane, and were only moderately resistant to perifosine compared with clone 10 (Fig. 1). This correlation between perifosine uptake and NBD-PE translocation therefore suggested that, as proposed previously [14], a link could exist between both processes in KB cells. We also tested the uptake rates of BODIPYlactosylceramide (raft-dependent endocytosis marker) and Alexa Fluor 488-dextran 10,000 (fluid phase endocytosis marker) in a subset of fourteen cell lines, and found no significant correlation upon comparing their rates of perifosine uptake (Fig. 2). 


\subsection{CDC50A is implicated in both perifosine and fluorescent}

\section{aminophospholipid analogues uptake in KB cells}

In our previous work we proposed that a putative APLT could be responsible for the internalization of both ALPs and aminophospholipids through the plasma membrane in human KB carcinoma cells. APLTs seems to be a functional complex of at least two proteins (alpha and beta subunits) $[10,18,19]$, and since fourteen different putative alpha but only three presumed beta subunits (CDC50A, B and C) have been described in humans, we decided to start our study of the potential implication of the latter proteins on perifosine uptake in mammalian cells. Since $C D C 50 C$ transcripts have been found to terminate aberrantly in humans [27], only CDC50A and $\mathrm{B}$ were likely to play a putative role in perifosine uptake. We therefore generated KB cells expressing CDC50A-V5 or CDC50B-V5 (Fig. 3A) and found that, whereas NBD-aminophospholipid uptake was increased by about $50 \%$ when either of these proteins was over-expressed, perifosine uptake was only boosted when CDC50A was over-expressed (Fig. 3B). No significant increase of NBD-PC uptake was detected in KB cells over-expressing CDC50A-V5 or CDC50B-V5. Interestingly, over-expression of CDC50A-V5 in KB PER-R clone10 cells did not increase the rate of perifosine or aminophospholipid uptake (data not shown). Moreover, knock-down of $\mathrm{CDC50A}$ and $\mathrm{CDC50B}$ reduced perifosine and NBD-aminophospholipid uptake to around $40 \%$ of the normal rate when CDC50A expression was lowered, whereas CDC50B silencing only affected NBD-aminophospholipid uptake (Fig. 4A). No significant reduction of NBD-PC was detected after the knock-down experiments. However, since we had no suitable antibody for monitoring the expression levels of endogenous $\mathrm{CDC50A}$ in $\mathrm{KB}$ cells, we also performed the same experiments in CDC50A-V5-transfected KB cells, thereby allowing us to monitor CDC50A-V5 
expression levels by Western blot (Fig. 4B). This study showed that lower CDC50AV5 levels correlated with lower rates of perifosine and NBD-aminophospholipid uptake (Fig. 4C).

\subsection{CDC50A subcellular localization in KB Wt vs. KB PER-R clone 10 cells}

Cdc50-Lem3p proteins play a role as both molecular chaperones needed for the correct folding and export of the alpha subunit P4-ATPase from the endoplasmic reticulum $(\mathrm{ER})[28,29]$, and also as catalytically relevant, integral components of the phospholipid translocation machinery [30]. Since we have found previously that human CDC50A appears to play a role in perifosine uptake in KB cells, we decided to establish the cellular localization of this protein. Thus, we performed indirect immunofluorescence of V5-tagged CDC50A expressed in KB cells and then visualized the samples by confocal microscopy. It is apparent from Fig. 5, which shows the scattered intracellular distribution and co-localization with several markers of different intracellular membrane compartments, that CDC50A-V5 is a membrane protein that is distributed via the endocytic and exocytic pathways in KB cells. However, we cannot conclude from this figure whether CDC50A-V5 reaches the plasma membrane or not. A comparison of KB and KB PER-R clone10 cells, both of which express similar levels of CDC50A-V5, as monitored by Western blot (not shown), highlighted a striking difference in the intracellular localization of CDC50AV5. Thus, this protein was expressed well at the ER level, and was also exported to the CIS-Golgi and TRANS-Golgi network (TGN) in both cell lines, whereas its presence in early and late endosomes was significantly lower in KB PER-R cells than in $\mathrm{KB}$ cells, thereby suggesting that $\mathrm{CDC} 50 \mathrm{~A}-\mathrm{V} 5$ distribution via the pathways 
connecting TGN, early endosomes, the plasma membrane and late endosomes is hindered in KB PER-R cells.

As we were unable to ascertain the presence of CDC50A at the plasma membrane of KB cells by confocal microscopy, we biotinylated the cell surface proteins in CDC50A-V5-transfected KB and KB PER-R cells in parallel. Fig. 6 shows that most of the CDC50A-V5 is intracellular (unbound fraction to streptavidinagarose beads) in KB cells, as also determined by confocal microscopy, but that a detectable amount of CDC50A-V5 reaches the plasma membrane as well. In contrast, no CDC50A-V5 was observable in the fraction of biotinylated cell surface proteins in KB PER-R clone10 cells, although its intracellular levels were comparable to those for KB cells. We used $\alpha$-tubulin as a reference to compare the amount of CDC50A-V5 expressed in both cell types and as a control of cell membrane integrity throughout the entire biotinylation process. Only cell surface proteins were biotinylated, since $\alpha$-tubulin is only present in the unbound fraction. The inability of CDC50A-V5 to reach the plasma membrane in KB PER-R cells is in agreement with its defective membrane trafficking, as suggested previously by confocal microscopy, and further supports our hypothesis that perifosine uptake is very low in this cell line due to the lack of a P4-ATPase APLT at the plasma membrane.

\subsection{CDC50A and Atp8b1 associate to exit the ER and traffic to the plasma membrane in HeLa and HEK293T cells, where they form a functional perifosine and aminophospholipid translocator}

In light of the functional involvement of CDC50A in perifosine uptake in KB cells, we decided to investigate whether CDC50A was also involved in perifosine uptake in 
other cell lines. Thus, we expressed CDC50A-V5 in HeLa and HEK-293T cells,

although with disappointing results: no increase was observed in perifosine or NBDphospholipid uptake in either of these cell lines (see Fig. 8B). However, this finding does not allow us to state that CDC50A plays no role in perifosine uptake in this case, as CDC50A may lack the appropriate alpha subunit partner in these cell lines. To test this hypothesis, we performed semi-quantitative RT-PCR to compare the mRNA expression levels of CDC50A and ATP8B1 (the best studied P4-ATPase [31], which was likely to be responsible for aminophospholipid translocation in these cell lines). This study showed (Fig. 7) that the endogenous expression levels of $C D C 50 A$ were similar in all three cell lines, and that ATP8B1 was expressed at similar levels in KB and HEK-293T cells, and at even higher levels in HeLa cells (Fig. 7). This finding suggests that a P4-ATPase other than ATP8B1 is likely to be the alpha subunit responsible for the APLT activity observed in KB, HeLa and HEK293T cells. At this point, instead of simply determining the expression levels of the remaining thirteen putative human alpha subunits, we adopted a more straightforward approach involving the simultaneous transfection of $C D C 50 A-V 5$ and murine Atp $8 b 1$ (a well-studied P4-ATPase, 95\% homologous to its human counterpart [34]) as a Cterminal myc-tagged protein in HeLa and HEK-293T cells (Fig. 8A). Interestingly, we found that the rates of perifosine uptake in HeLa and HEK-293T cells increased by $60 \%$ and $130 \%$, respectively (Fig. 8B). The uptake of NBD-aminophospholipids (but not NBD-PC) was also similarly boosted in both cell lines (Fig. 8B). Confocal microscopy studies revealed that CDC50A-V5 was retained in the intracellular membrane compartments in HeLa cells when over-expressed alone, whereas when it was co-expressed with Atp8b1 in the same cells (Fig. 9), both proteins co-localized at the plasma membrane, in a similar manner to that reported for the pair ATP8B1 + 
CDC50A [29]. Co-localization of these two proteins was also observed when coexpressed in HEK-293T cells (data not shown).

\section{DISCUSSION}

A detailed knowledge of the molecular mechanism of action of anticancer drugs will help to identify those patients who are most likely to respond to a given treatment based on such drugs, to overcome drug resistance phenomena and to improve the final treatment outcome. Indeed, there seems to be a general consensus amongst researchers regarding the manner in which perifosine causes cell death in several different types of cancer cells. However, some discrepancies have arisen concerning how perifosine enters cancer cells, and what previous steps are required for the drug to reach its intracellular targets and trigger cell death. Thus, it has been proposed that ALP enters cells either by raft-dependent endocytosis [13, $32,33]$ or by transporter-mediated translocation of perifosine through the plasma membrane $[14,15,16]$.

We firmly support the latter hypothesis, and in this present work, which is a continuation of a previous study [14], we present strong evidence to suggest that perifosine enters cancer cells via APLT(s) at the plasma membrane, and that CDC50A plays a key role in this process. Thus, we have found a positive correlation between perifosine uptake and NBD-aminophospholipid translocation (a wellestablished marker for aminophospholipid translocase activity) in several KB clones obtained in our laboratory. Furthermore, we found no correlation whatsoever between perifosine uptake and endocytosis rates in a subset of fourteen cell lines, which is in stark contrast with previous works where the role of raft-dependent endocytosis in perifosine uptake has been proposed [13, 32, 33]. This discrepancy 
may, however, only be apparent if we consider that only adherent cell lines, but no leukemia or lymphoma cells, were used in the present study, whereas the authors who proposed the raft-dependent hypothesis for perifosine uptake have recently published a further study [15] where they discriminate between lymphoma and carcinoma cells on the basis of their prevalent perifosine-uptake mechanism (raftdependent endocytosis in the former, and a plasma membrane translocator in the latter). It is also possible that both mechanisms of perifosine uptake could co-exist in the same cell, with their relative importance varying with cell type. Thus, for example, KB cells accumulate perifosine very rapidly, and independently of rafts endocytosis, due to their high APLT activity $[14,15]$, whereas HeLa cells accumulate perifosine five times slower as they exhibit lower APLT activity. In this case, the slow drug uptake would depend mainly on endocytosis, as suggested previously [33].

We also found that modulating the CDC50A expression levels in KB cells markedly affected the rate of perifosine and aminophospholipid uptake, thereby suggesting that a putative APLT is responsible for translocation of both types of molecules through the plasma membrane. It also appears that the CDC50A beta subunit should be the limiting factor for the APLT complex in KB cells, where it is distributed throughout the endo-membranous compartments, trafficking from the ER to the plasma membrane of KB cells. In contrast, CDC50A exports from the ER only to the TGN in KB PER-R clone10 cells and does not reach the cell surface, thereby suggesting that these perifosine-resistant cells harbor a defect that results in the incorrect trafficking of CDC50A at this point of the exocytic pathway. Since CDC50A must couple with a P4-ATPase for correct trafficking of the full APLT complex to the plasma membrane [29], the observed traffic defect of CDC50A in KB PER-R cells could explain the inability of this cell line to translocate perifosine. In contrast to KB 
cells, over-expression of CDC50A in the human cell lines HeLa and HEK-293T did not modulate perifosine uptake, thus suggesting that, in this case, the alpha subunit rather than CDC50A may be the limiting component of the putative APLT. Human ATP8B1 is a P4-ATPase with APLT activity when complexed with CDC50A, although the expression levels of both CDC50A and ATP8B1 in HeLa and HEK293T cells were found to be very similar to those in KB. Therefore, if we assume that no differential regulation of the APLT complex occurs in each cell line, and that the overall APLT activity depends mainly on the relative expression levels of its two components, it seems likely that ATP8B1 is not the alpha subunit responsible for the different APLT activities measured in these cell lines. However, we found that the uptake of perifosine and NBD-aminophospholipids (but not NBD-PC) increased remarkably when both HeLa and HEK-293T cells were co-transfected with Atp8b1myc and CDC50A-V5. Moreover, CDC50A-V5 remained intracellular when overexpressed alone, but when co-expressed with Atp8b1 both proteins exported from the ER and co-localized at the plasma membrane, as is the case with human ATP8B1 + CDC50A [29]. CDC50A may be coupled with a P4 ATPase to drive perifosine and aminophospholipids uptake and could contribute to the transport specificity of the complex.

Taken together, the results of this work strongly support the role of an APLT as the means of entry of the anticancer drug perifosine through the plasma membrane in adherent carcinoma cells. Such an APLT in humans is most likely formed by the beta subunit CDC50A plus a P4-ATPase alpha subunit(s) whose identity remains to be established. 


\section{ACKNOWLEDGEMENTS}

This work was supported by "Plan Andaluz de Investigación, Proyecto de Excelencia (CTS 187)", Junta de Andalucia. We acknowledge Aeterna Zentaris (Frankfurt, Germany) for the financial support and for providing the perifosine and $\left[{ }^{14} \mathrm{C}\right]$-perifosine used in this study. We want to thank Carlos Castillo Pérez for his help in the fixing and cloning of Atp8b1 cDNA and Dr. Luis Carvalho for his technical assistance in RT-PCR experiments.

\section{REFERENCES}

[1] Kondapaka SB, Singh SS, Dasmahapatra GP, Sausville EA, Roy KK. Perifosine, a novel alkylphospholipid, inhibits protein kinase B activation. Mol Cancer Ther 2003;2:1093-103.

[2] Gills JJ, Dennis PA. Perifosine: update on a novel Akt inhibitor. Curr Oncol Rep 2009;11:102-10.

[3] Chee KG, Longmate J, Quinn DI, Chatta G, Pinski J, Twardowski P, et al. The AKT inhibitor perifosine in biochemically recurrent prostate cancer: a phase II California/Pittsburgh cancer consortium trial. Clin Genitourin Cancer $2007 ; 5: 433-7$.

[4] Leighl NB, Dent S, Clemons M, Vandenberg TA, Tozer R, Warr DG, et al. A Phase 2 study of perifosine in advanced or metastatic breast cancer. Breast Cancer Res Treat 2008;108:87-92.

[5] Argiris A, Cohen E, Karrison T, Esparaz B, Mauer A, Ansari R, et al. A phase II trial of perifosine, an oral alkylphospholipid, in recurrent or metastatic head and neck cancer. Cancer Biol Ther 2006;5:766-70. 
[6] Knowling M, Blackstein M, Tozer R, Bramwell V, Dancey J, Dore N, et al. A phase II study of perifosine (D-21226) in patients with previously untreated metastatic or locally advanced soft tissue sarcoma: A National Cancer Institute of Canada Clinical Trials Group trial. Invest New Drugs 2006;24:4359.

[7] Hennessy BT, Lu Y, Poradosu E, Yu Q, Yu S, Hall H, et al. Pharmacodynamic markers of perifosine efficacy. Clin Cancer Res 2007;13:7421-31.

[8] Hanson PK, Malone L, Birchmore JL, Nichols JW. Lem3p is essential for the uptake and potency of alkylphosphocholine drugs, edelfosine and miltefosine. J Biol Chem 2003;278:36041-50.

[9] Riekhof WR, Voelker DR. The yeast plasma membrane P4-ATPases are major transporters for lysophospholipids. Biochim Biophys Acta 2009;1791:620-7.

[10] Pérez-Victoria FJ, Sanchez-Cañete MP, Castanys S, Gamarro F. Phospholipid translocation and miltefosine potency require both $\mathrm{L}$. donovani miltefosine transporter and the new protein LdRos3 in Leishmania parasites. J Biol Chem 2006;281:23766-75.

[11] Gajate C, Fonteriz RI, Cabaner C, Álvarez-Noves G, Álvarez-Rodríguez Y, Modolell M, et al. Intracellular triggering of Fas, independently of FasL, as a new mechanism of antitumor ether lipid-induced apoptosis. Int $\mathrm{J}$ Cancer 2000;85:674-82.

[12] Mollinedo F, Fernández-Luna JL, Gajate C, Martin-Martin B, Benito A, Martínez-Dalmau R, et al. Selective induction of apoptosis in cancer cells by the ether lipid ET-18-OCH3 (Edelfosine): molecular structure requirements, 
cellular uptake, and protection by Bcl-2 and Bcl-X(L). Cancer Res $1997 ; 57: 1320-8$.

[13] van der Luit AH, Vink SR, Klarenbeek JB, Perrissoud D, Solary E, Verheij M, et al. A new class of anticancer alkylphospholipids uses lipid rafts as membrane gateways to induce apoptosis in lymphoma cells. Mol Cancer Ther $2007 ; 6: 2337-45$.

[14] Muñoz-Martínez F, Torres C, Castanys S, Gamarro F. The anti-tumor alkylphospholipid perifosine is internalized by an ATP-dependent translocase activity across the plasma membrane of human KB carcinoma cells. Biochim Biophys Acta 2008;1778:530-40.

[15] Vink SR, van der Luit AH, Klarenbeek JB, Verheij M, van Blitterswijk WJ. Lipid rafts and metabolic energy differentially determine uptake of anti-cancer alkylphospholipids in lymphoma versus carcinoma cells. Biochem Pharmacol $2007 ; 74: 1456-65$.

[16] Menez C, Buyse M, Farinotti R, Barratt G. Inward translocation of the phospholipid analogue miltefosine across Caco- 2 cell membranes exhibits characteristics of a carrier-mediated process. Lipids 2007;42:229-40.

[17] Pérez-Victoria FJ, Gamarro F, Ouellette M, Castanys S. Functional cloning of the miltefosine transporter. A novel P-type phospholipid translocase from Leishmania involved in drug resistance. J Biol Chem 2003;278:49965-71.

[18] Sanchez-Cañete MP, Carvalho L, Pérez-Victoria FJ, Gamarro F, Castanys S. Low plasma membrane expression of the miltefosine transport complex renders Leishmania braziliensis refractory to the drug. Antimicrob Agents Chemother 2009;53:1305-13. 
[19] Saito K, Fujimura-Kamada K, Furuta N, Kato U, Umeda M, Tanaka K. Cdc50p, a protein required for polarized growth, associates with the Drs2p Ptype ATPase implicated in phospholipid translocation in Saccharomyces cerevisiae. Mol Biol Cell 2004;15:3418-32.

[20] Folmer DE, Elferink RP, Paulusma CC. P4 ATPases - lipid flippases and their role in disease. Biochim Biophys Acta 2009;1791:628-35.

[21] Katoh Y, Katoh M. Identification and characterization of CDC50A, CDC50B and CDC50C genes in silico. Oncol Rep 2004;12:939-43.

[22] Evers R, Cnubben NH, Wijnholds J, van Deemter L, van Bladeren PJ, Borst P. Transport of glutathione prostaglandin A conjugates by the multidrug resistance protein 1. FEBS Lett 1997;419:112-6.

[23] Cailleau R, Young R, Olive M, Reeves WJ, Jr. Breast tumor cell lines from pleural effusions. J Natl Cancer Inst 1974;53:661-74.

[24] Soule HD, Vazguez J, Long A, Albert S, Brennan M. A human cell line from a pleural effusion derived from a breast carcinoma. J Natl Cancer Inst 1973;51:1409-16.

[25] Hooijberg JH, Broxterman HJ, Kool M, Assaraf YG, Peters GJ, Noordhuis P, et al. Antifolate resistance mediated by the multidrug resistance proteins MRP1 and MRP2. Cancer Res 1999;59:2532-5.

[26] Lario A, González A, Dorado G. Automated laser-induced fluorescence DNA sequencing: equalizing signal-to-noise ratios significantly enhances overall performance. Anal Biochem 1997;247:30-3.

[27] Osada N, Hashimoto K, Hirai M, Kusuda J. Aberrant termination of reproduction-related TMEM30C transcripts in the hominoids. Gene 2007;392:151-6. 
[28] Puts CF, Holthuis JC. Mechanism and significance of P4 ATPase-catalyzed lipid transport: lessons from a $\mathrm{Na}+/ \mathrm{K}_{+}-$pump. Biochim Biophys Acta 2009;1791:603-11.

[29] Paulusma CC, Folmer DE, Ho-Mok KS, de Waart DR, Hilarius PM, Verhoeven AJ, et al. ATP8B1 requires an accessory protein for endoplasmic reticulum exit and plasma membrane lipid flippase activity. Hepatology 2008;47:268-78.

[30] Lenoir G, Williamson P, Puts CF, Holthuis JC. Cdc50p plays a vital role in the ATPase reaction cycle of the putative aminophospholipid transporter Drs2p. J Biol Chem 2009;284:17956-67.

[31] Paulusma CC, Oude Elferink RP. The type 4 subfamily of P-type ATPases, putative aminophospholipid translocases with a role in human disease. Biochim Biophys Acta 2005;1741:11-24.

[32] van der Luit AH, Budde M, Ruurs P, Verheij M, van Blitterswijk WJ. Alkyllysophospholipid accumulates in lipid rafts and induces apoptosis via raftdependent endocytosis and inhibition of phosphatidylcholine synthesis. J Biol Chem 2002;277:39541-7.

[33] Van Der Luit AH, Budde M, Verheij M, Van Blitterswijk WJ. Different modes of internalization of apoptotic alkyl-lysophospholipid and cell-rescuing lysophosphatidylcholine. Biochem J 2003;374:747-53.

[34] Paulusma CC, Groen A, Kunne C, Ho-Mok KS, Spijkerboer AL, Rudi de Waart $\mathrm{D}$, et al. Atp8b1 deficiency in mice reduces resistance of the canalicular membrane to hydrophobic bile salts and impairs bile salt transport. Hepatology 2006;44:195-204. 


\section{FIGURE LEGENDS}

Figure 1. Correlation between perifosine sensitivity and ${ }^{14} \mathrm{C}$-perifosine and NBD-PE uptake in KB Wt cells and different KB PER-R clones. Perifosine sensitivity $\left(\mathrm{EC}_{50}\right.$ values) was determined by MTT assay after incubation for $2 \mathrm{~h}$ with different drug concentrations. Uptake of $1 \mu \mathrm{M}\left[{ }^{14} \mathrm{C}\right]$-perifosine $(0.03 \mu \mathrm{Ci} / \mathrm{mL})$ and $2 \mu \mathrm{M}$ NBD-PE was performed at $37^{\circ} \mathrm{C}$ for $1 \mathrm{~h}$ and $10^{\circ} \mathrm{C}$ for $20 \mathrm{~min}$, respectively, as described previously [14]. Data were normalized to those measured in $\mathrm{KB} \mathrm{Wt}$, which were considered as $100 \%$. The values shown are the average \pm SD of three to six different experiments performed in triplicate.

Figure 2. Comparative analysis of perifosine and endocytosis markers in different representative cell lines. Perifosine-uptake experiments were performed as described in the legend to Fig. 1. Uptake of the endocytic markers BODIPY-Lactosyl-ceramide (LacCER, $0.5 \mu \mathrm{M}$ ) and Alexa488-labelled dextran $10 \mathrm{KD}$ (Dextran $10 \mathrm{KDa}, 0.25 \mathrm{mg} / \mathrm{mL}$ ) was performed for 7 min at $37^{\circ} \mathrm{C}$ and analyzed by flow cytometry as described previously [14]. Bars represent the average \pm S.D. of three different experiments performed in duplicate. Data were normalized to those measured in KB Wt cells, which were considered as $100 \%$.

Figure 3. Uptake of perifosine and NBD-phospholipids in KB Wt cells overexpressing CDC50A or CDC50B. A) Western blot analysis. KB Wt cells were transfected with pEF6-V5 vector containing the corresponding gene in phase with a Cterminal V5-tag. Expression levels were determined using anti-V5 monoclonal antibody. A blot using anti-a-tubulin was performed in parallel as control of protein loading. B) 
Uptake experiments. Uptake of perifosine and NBD-PE, -PS and -PC was performed as described in the legend to Fig. 1. This is a representative experiment performed twice in triplicate \pm S.D. from two different transfections. Data were normalized to those measured in KB Wt cells (perifosine uptake: $3082 \pm 151 \mathrm{pmol} / \mathrm{mg}$ protein; NBDphospholipids uptake expressed in flow cytometry mean channel values after substracting the cell autofluorescence: NBD-PE: $558 \pm 57$; NBD-PS: $497 \pm 63$; NBD-PC: $463 \pm 84$ ), which were considered as $100 \%$.

Figure 4. Silencing of $\mathrm{CDC50A}$ and $\mathrm{CDC50B}$ in KB Wt cells. A) Uptake of NBDphospholipids and perifosine. KB Wt was transfected with $100 \mathrm{nM}$ specific SMARTpool CDC50A or CDC50B siRNA oligonucleotides and the uptake of $\left[{ }^{14} \mathrm{C}\right]$-perifosine and NBD-PE and -PC determined as described in the legend to Figure 1. The figure shows a representative experiment performed in triplicate $\pm S D$ of four independent experiments. Data were normalized to that measured in DharmaFECT 1 treated (transfectant agent without siRNAs) KB Wt cells (perifosine uptake: $3450 \pm 96$ pmol/mg protein; NBD-phospholipids uptake expressed in flow cytometry mean channel values after substracting the cell autofluorescence: NBD-PE: $597 \pm 28$; NBD-PC: $513 \pm 49$ ), which was considered as $100 \%$. B) Western blot showing the increasing reduction of CDC50A-V5 expression in CDC50A-V5-transfected $\mathrm{KB} \mathrm{Wt}$ cells at increasing concentrations of the specific siRNA. A blot using anti-a-tubulin was performed in parallel as control of protein loading. C) The same as in A) but targeting=only CDC50AV5 transfected cells with 1, 10 or $100 \mathrm{nM}$ specific CDC50A siRNA oligonucleotides and determination of $\left[{ }^{14} \mathrm{C}\right]$-perifosine and NBD-PE, -PS and -PC uptake. The figure shows a representative experiment performed in triplicate \pm SD of five independent experiments. 
The absolute uptake values measured in KB Wt cells with Dharmafect 1 in this set of experiments were: perifosine: $3657 \pm 162 \mathrm{pmol} / \mathrm{mg}$ protein; NBD-phospholipids uptake expressed in flow cytometry mean channel values after substracting the cell autofluorescence: NBD-PE: $609 \pm 71$; NBD-PS: $505 \pm 63$; NBD-PC: $521 \pm 66$.

Figure 5. CDC50A subcellular localization by confocal microscopy analysis. $\mathrm{KB} \mathrm{Wt}$ and KB PER-R clone 10 cells transfected with CDC50A-V5 were fixed and immunostained as described in section 2.9. Different protein markers specific for each subcellular compartment (green) were used to track the presence of CDC50A-V5 (red) in each of them (yellow pixels denote the co-localization of CDC50A-V5). The pictures are representative of at least three different microscopic fields per sample of fixed and immunostained cells. Three different cell samples from different days and different transfection batches were processed for each cell line and visualized under the microscope, in order to confirm that the intracellular distribution of CDC50A-V5 was not an artefact of the transfection procedure, cell batch or culture conditions.

Figure 6. Cell-surface expression of CDC50A. KB Wt and KB PER-R clone10 cells transfected with CDC50A-V5 were biotinylated as described in section 2.7. Samples were subjected to SDS-PAGE and immunoblotted with anti-V5 antibodies. Immunoblot of a-tubulin, a typical cytoplasmic protein, was used as control of plasma membrane integrity. The unbound fraction represents proteins that could not be biotinylated with the EZ-Link NHS-Biotin reagent, since the labeling was performed in whole cells with intact plasma membrane, and only surface proteins could be labeled (avidin-bound fraction). 
Figure 7. $C D C 50 A$ and $A T P 8 B 1 \mathrm{mRNA}$ levels in different cell lines. Semi-quantitative

RT-PCRs showing the relative mRNA levels of CDC50A, ATP8B1 and $\beta$-actin (control) in KB, HeLa and HEK-293T human cell lines were performed as described in section 2.10. Aliquots of the undiluted (1) and 10-fold diluted (1:10) cDNAs were used as template in the PCR reactions.

Figure 8. Uptake of NBD-phospholipids and perifosine in cells over-expressing both CDC50A and Atp8b1. A) Western blot showing the over-expression of CDC50A-V5 and Atp8b1-myc in HeLa and HEK-293T cells. A blot using anti-a-tubulin was performed in parallel as control of protein loading. B) Effect of the co-expression of the two proteins on the accumulation of NBD-PC, -PE, -PS and ${ }^{14} \mathrm{C}$-perifosine. Uptake experiments were performed as described in the legend to Fig. 1. The histograms represent the average \pm S.D. of two different experiments performed in triplicate. The absolute uptake values measured in HeLa cells were: perifosine: $726 \pm 123 \mathrm{pmol} / \mathrm{mg}$ protein; NBD-PE: $313 \pm$ 29; NBD-PS: $272 \pm 17$; NBD-PC: $313 \pm 45$. In HEK293T cells were: perifosine: $877 \pm 27$ pmol/mg protein; NBD-PE: $446 \pm 48$; NBD-PS: $340 \pm 53$; NBD-PC: $403 \pm 81$. NBDphospholipids uptake expressed in flow cytometry mean channel values after substracting the cell autofluorescence

Figure 9. Confocal microscopy analysis of the co-expression of CDC50A and Atp8b1 in human cancer cells. HeLa cells were co-transfected with CDC50A-V5 and Atp8b1myc, fixed and immunostained with anti-V5 (red) and anti-myc (green) antibodies as described in section 2.9. Arrowheads indicate cells co-expressing both proteins, which also co-localize at the cell surface. 


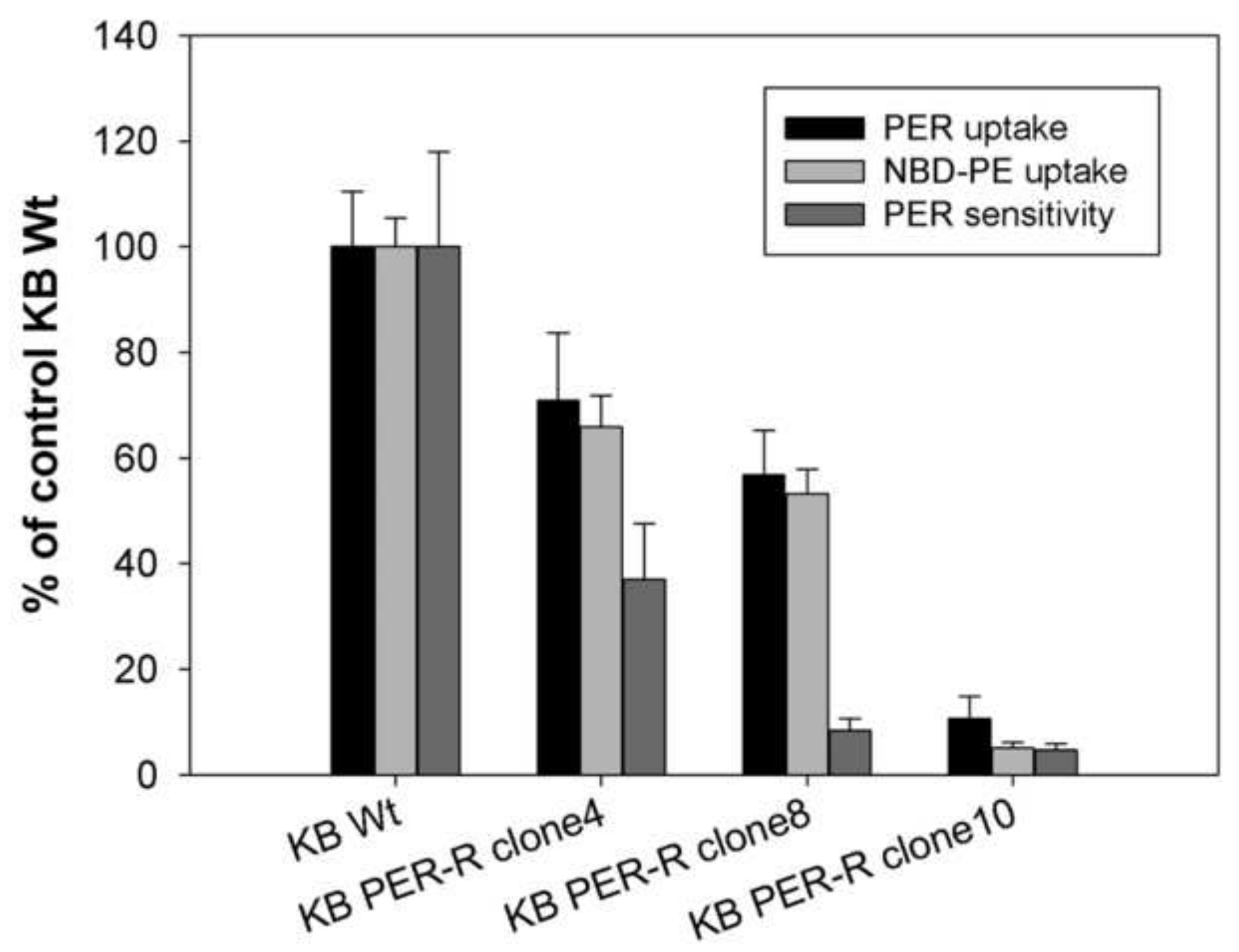




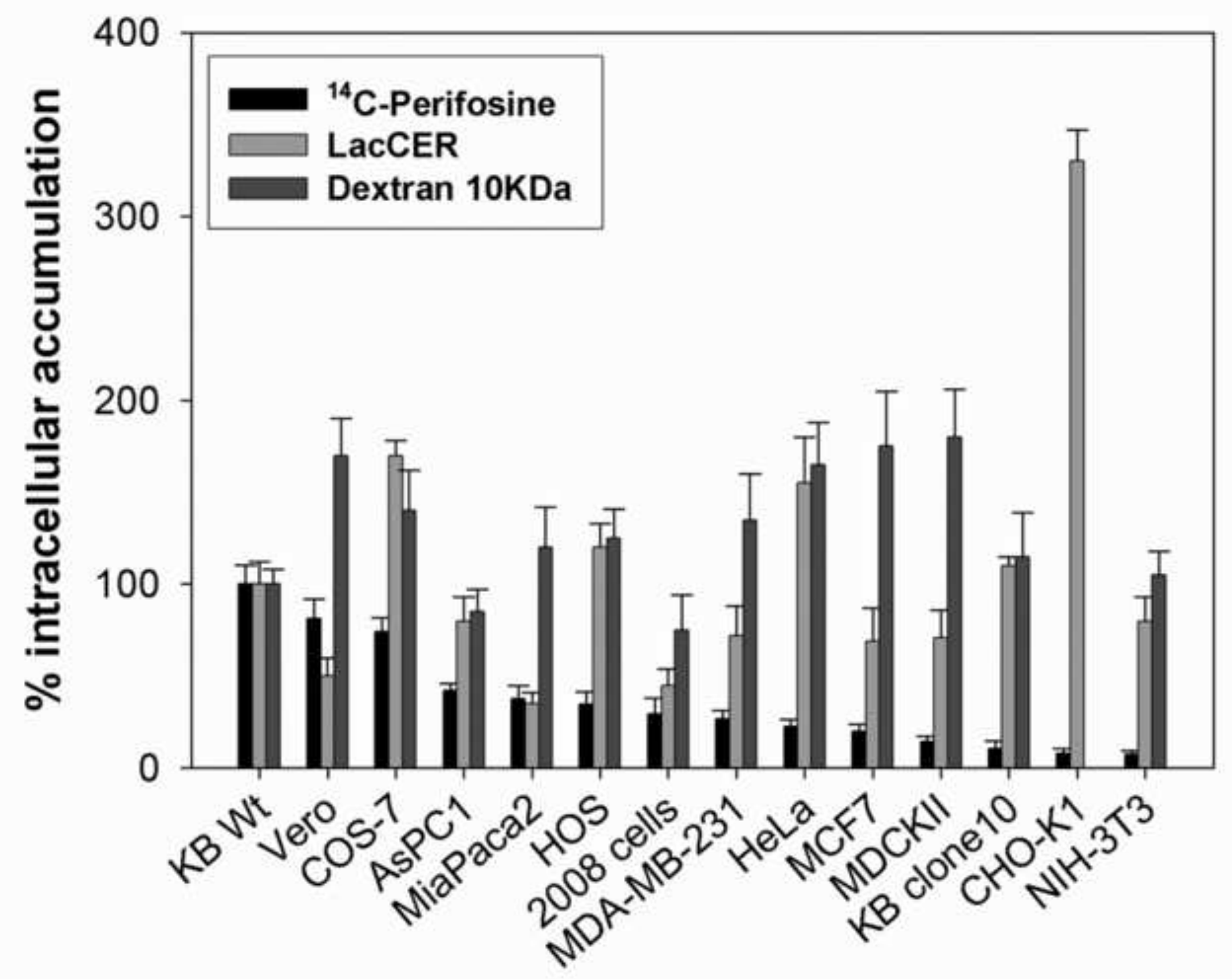

rage зU от з 
A

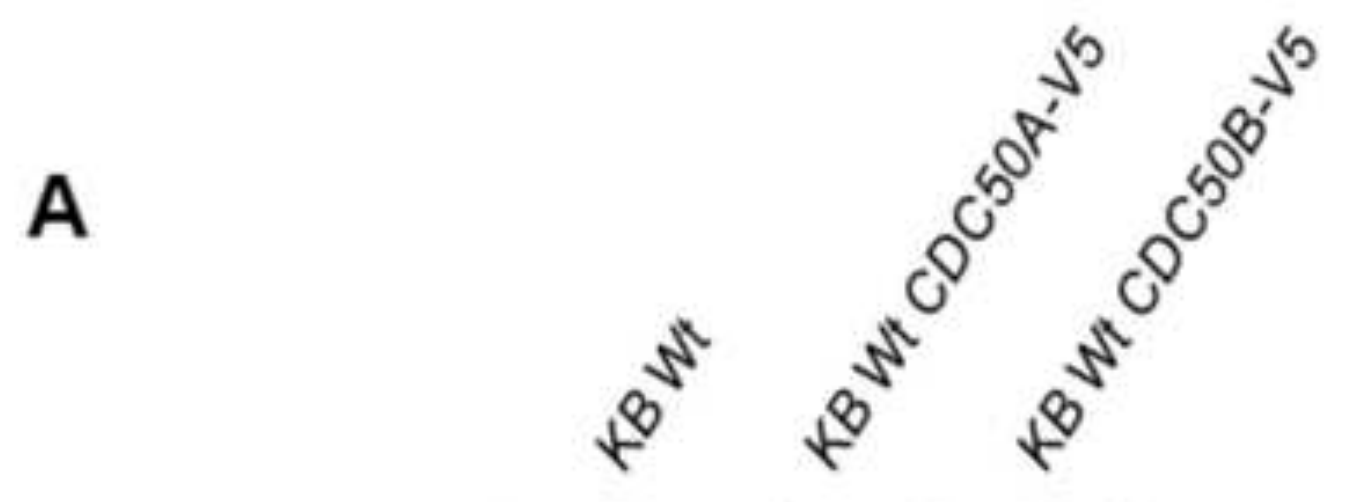

Anti-V5

$\alpha$-tubulin

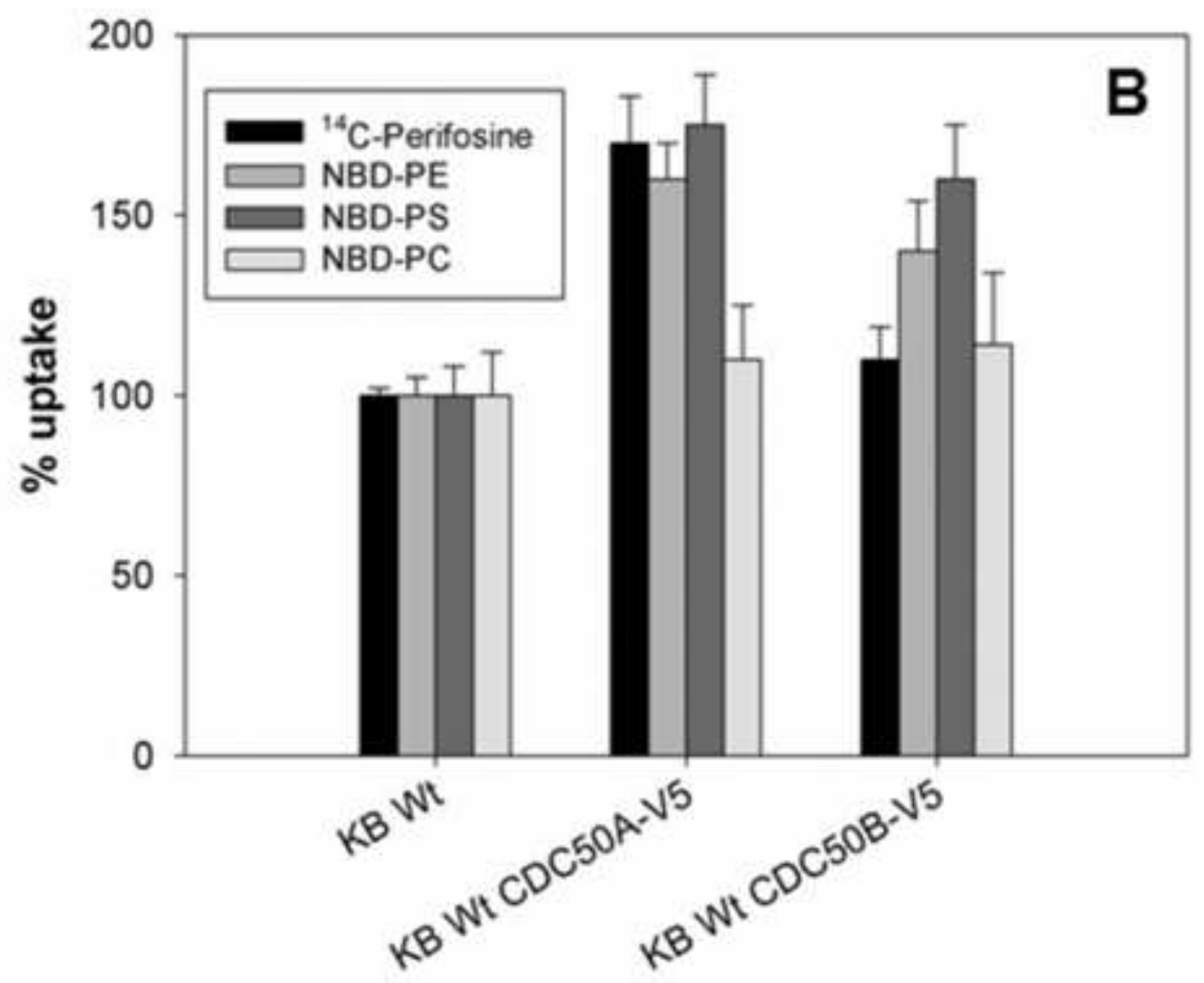



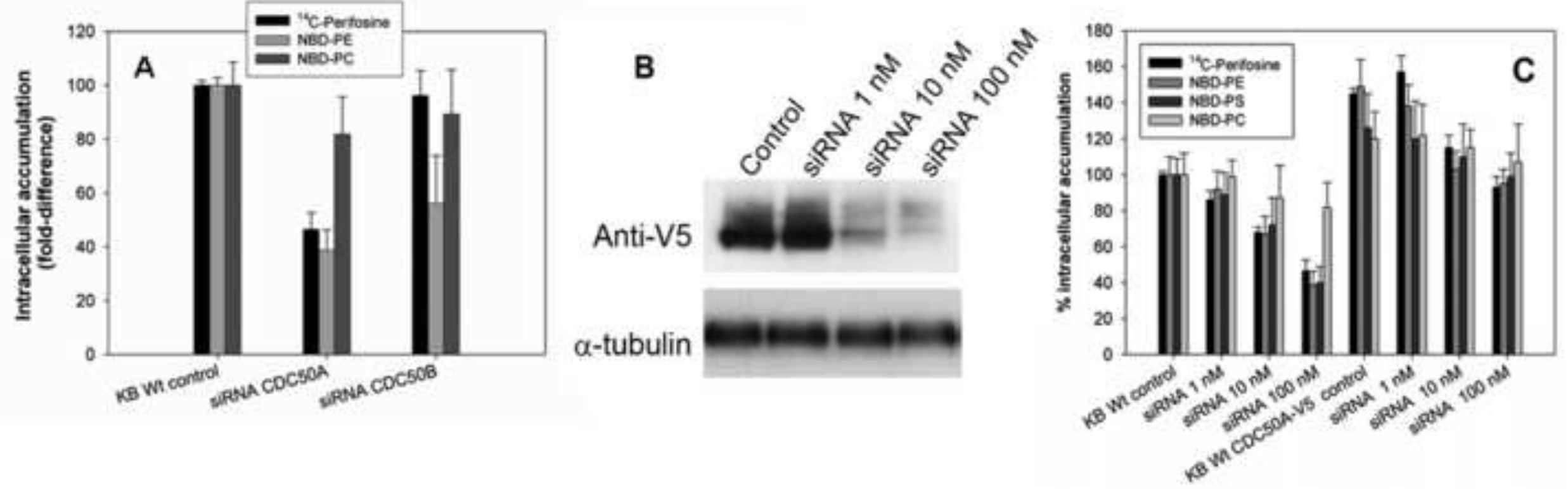

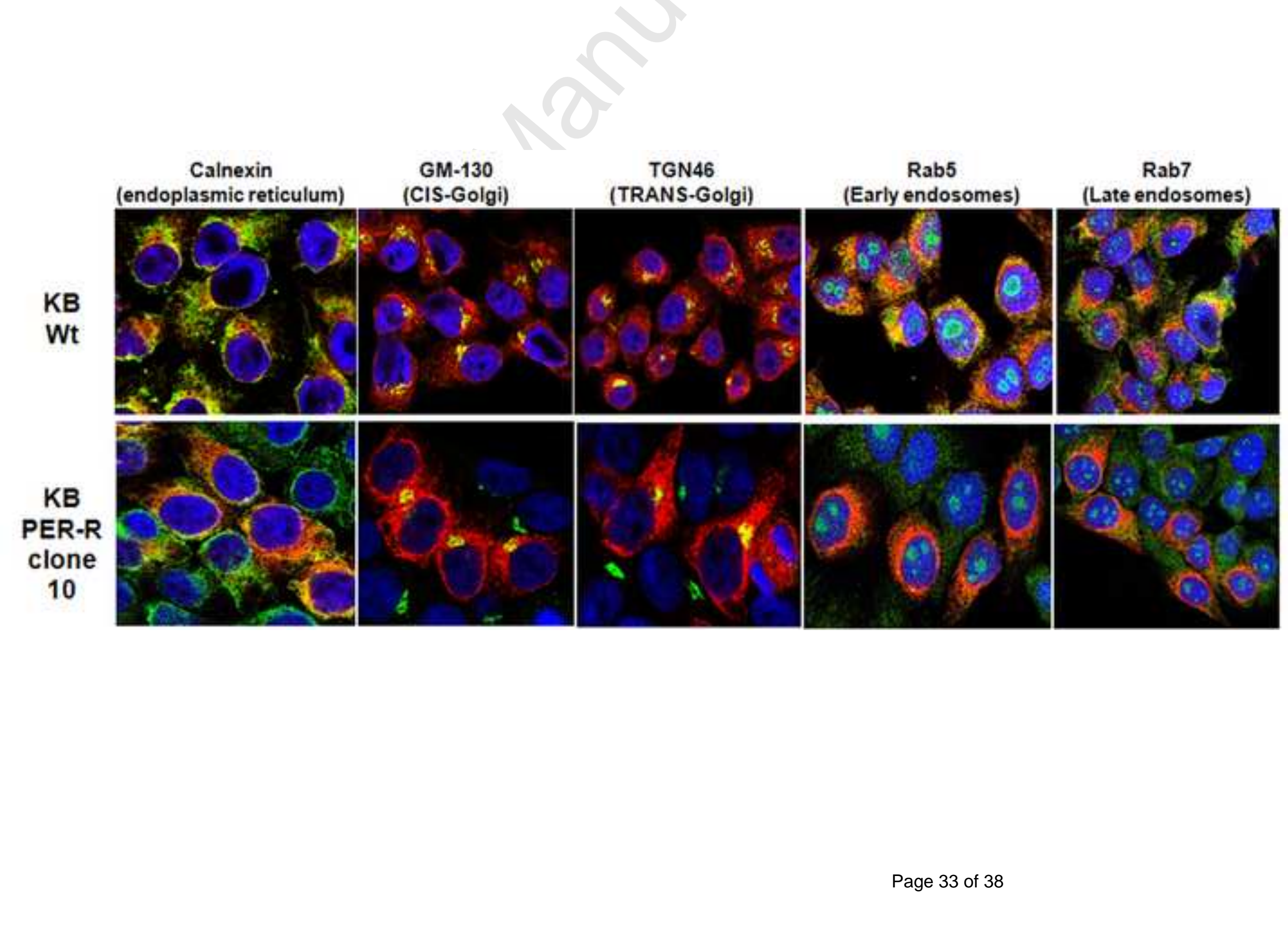

(2)

\section{列}

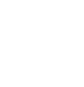




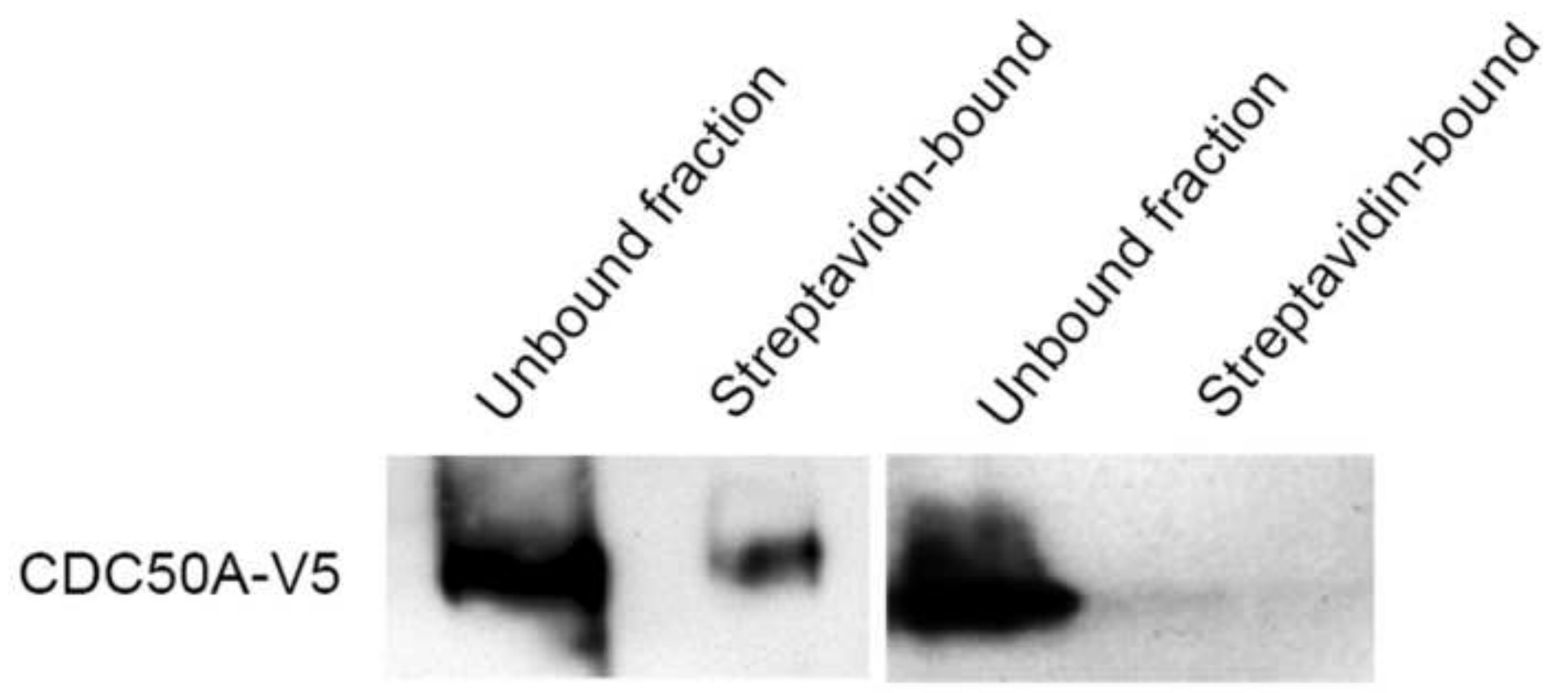

$\alpha-$ tubulin 

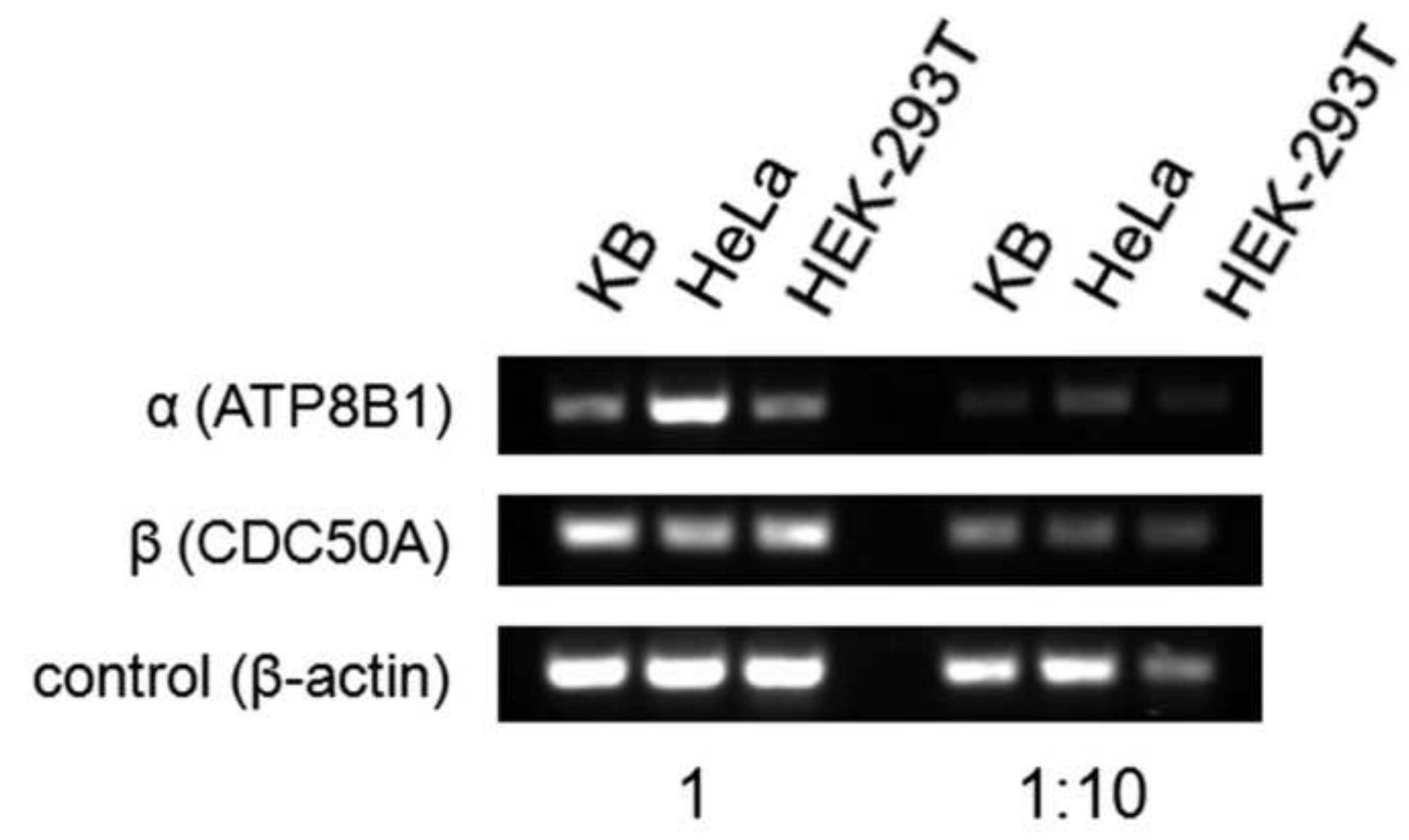

control ( $\beta$-actin)

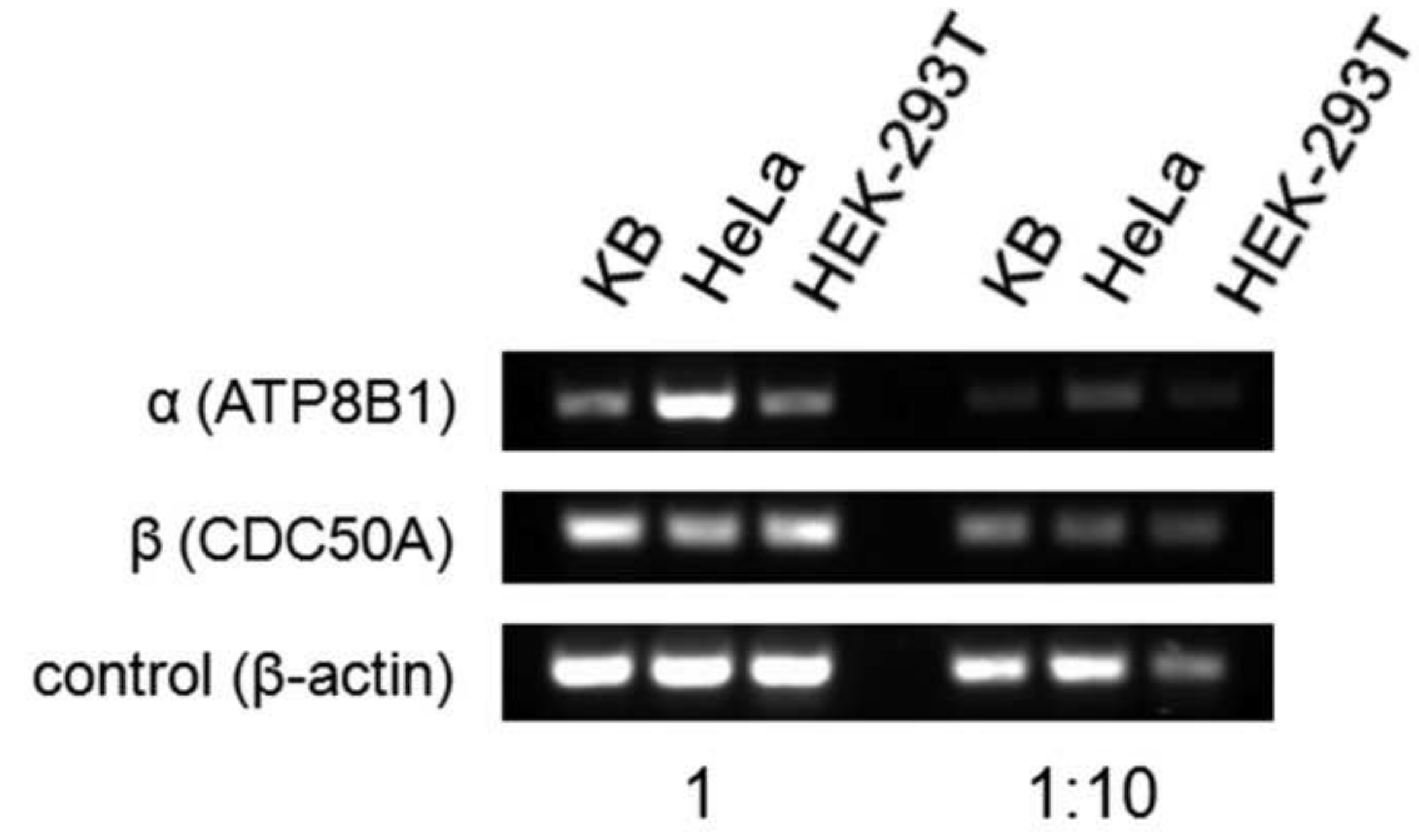




\section{CDC50A-V5 ATP8B1-myc MERGE}
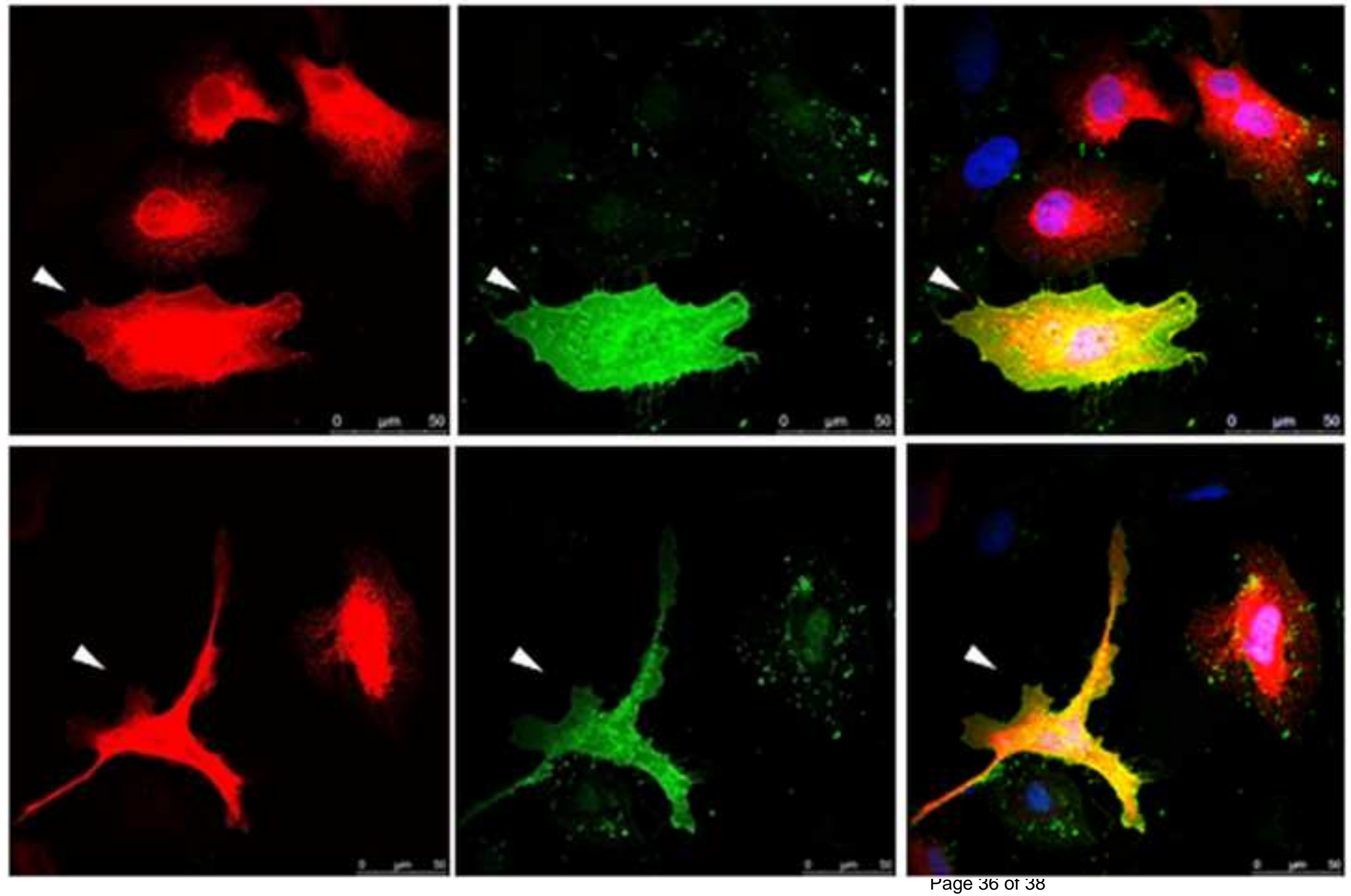

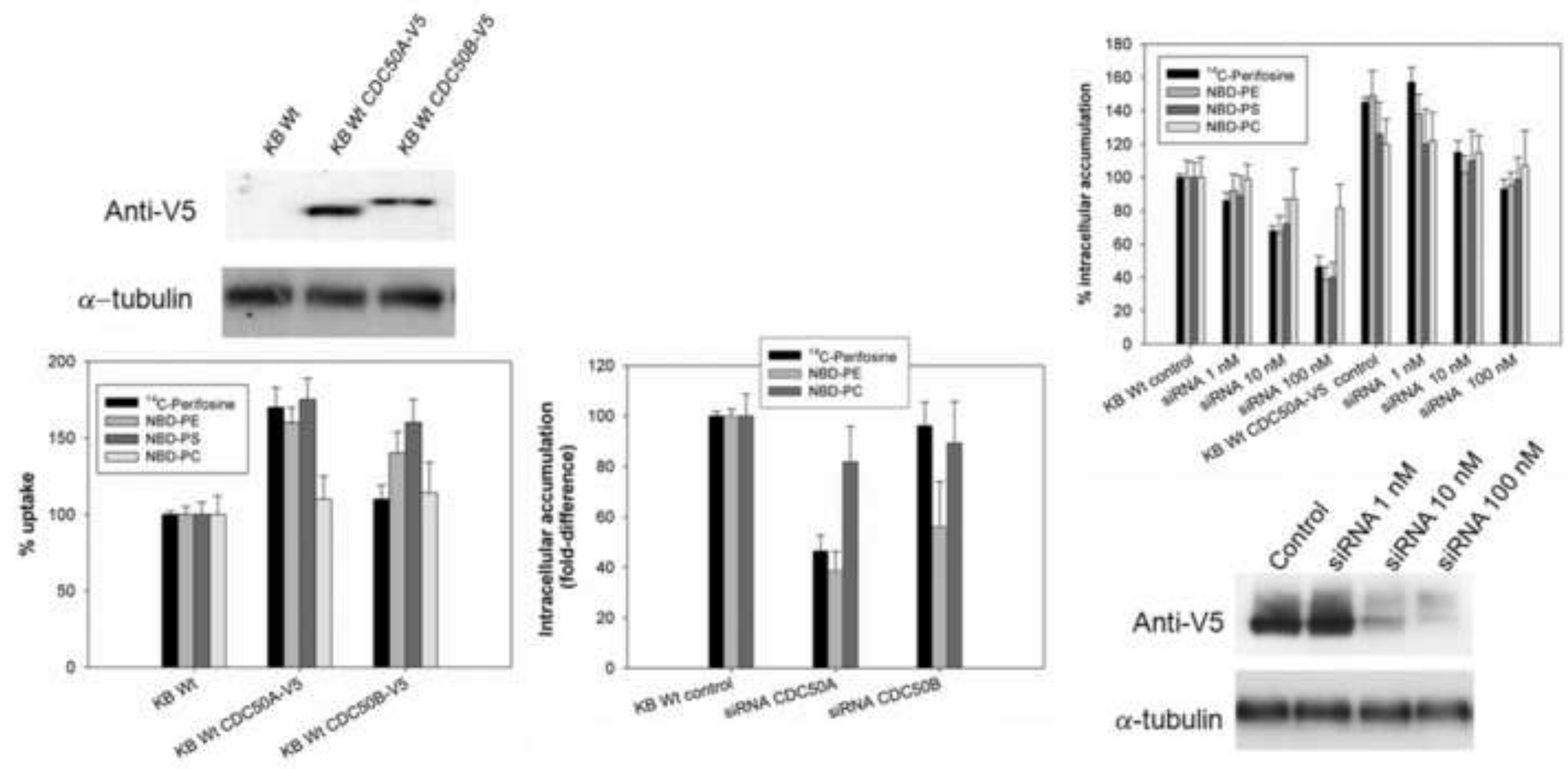
A

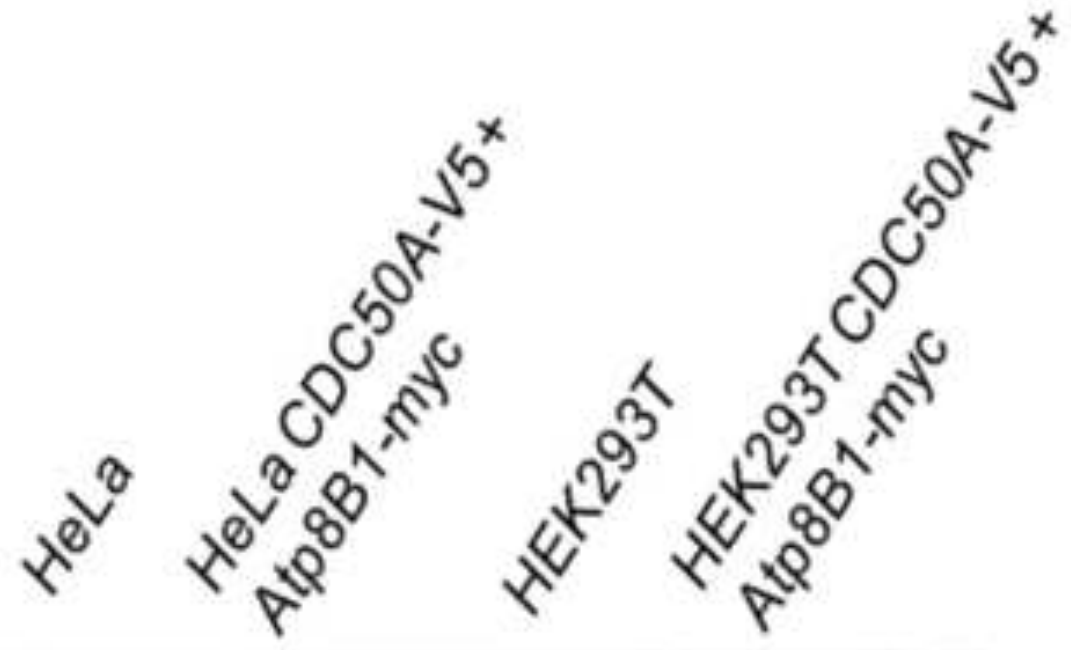

Anti-V5

Anti-myc

$\alpha$-tubulin

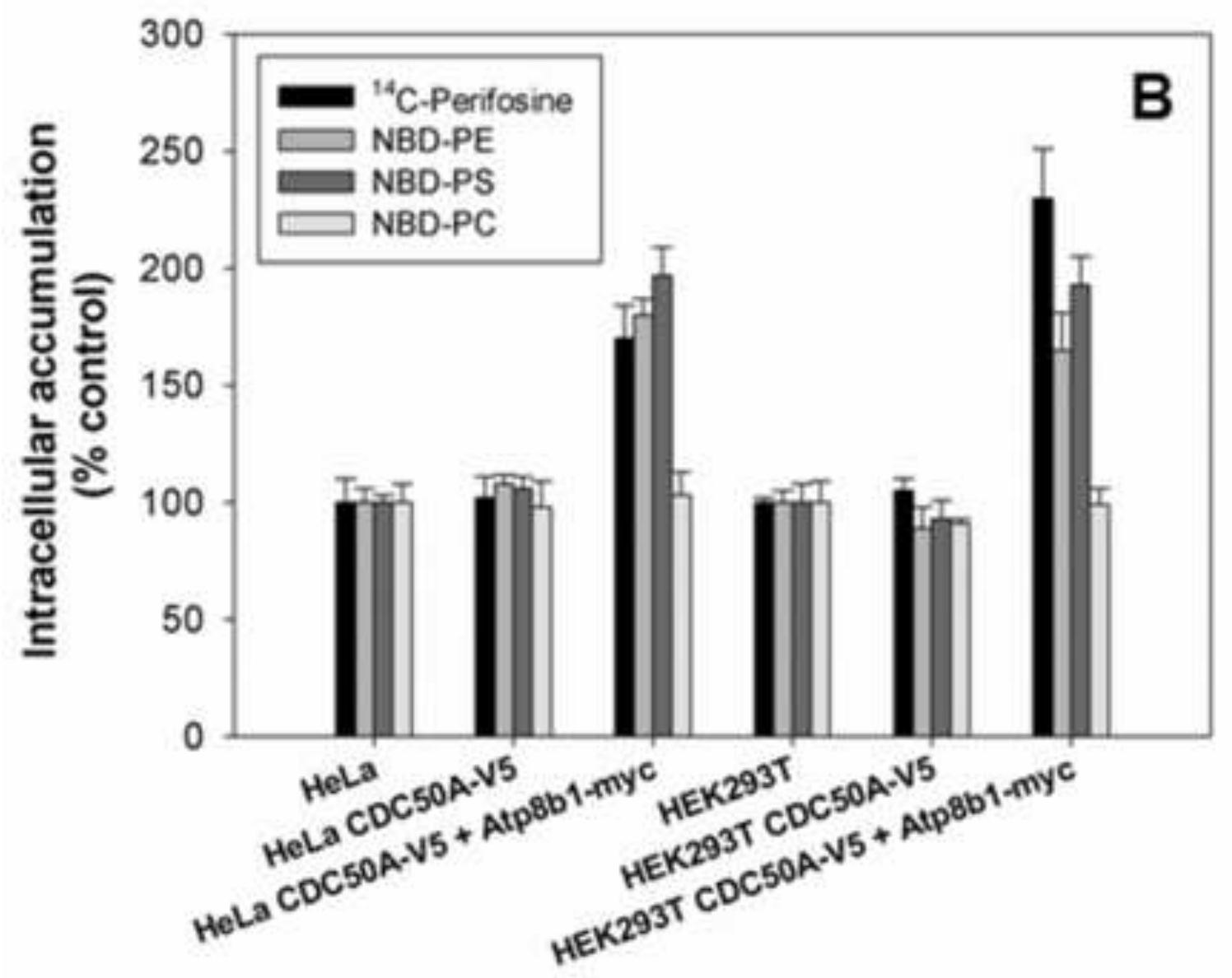

